Capabilities-based Gender Equality Analysis of Educational Policy-making and Reform in Turkey

Firdevs Melis Cin ${ }^{\mathrm{a}^{*}}$, Ecem Karlıdağ-Dennis ${ }^{\mathrm{b}}$ Zeynep Temiz ${ }^{\mathrm{c}}$

$a^{a *}$ Lancaster University, Department of Educational Research, UK

Educational Research County South Lancaster University Lancaster United Kingdom LA1 4YD Email:.m.cin@lancaster.ac.uk

*Corresponding Author

${ }^{\mathrm{b}}$ The University of Northampton University, Institute for Social Innovation and Impact, UK Park Campus

Boughton Green Road

Northampton

NN2 7AL

Email: Ecem.Karlidag-Dennis@northampton.ac.uk

c Yüzüncü Y11 Üniversitesi, Department of Early Childhood Education, Van, Turkey Bardakçı Mahallesi, Yüzüncü Y1l Üniversitesi Kampüsü, 65090 Tuşba/Van, Turkey

e-mail: cimenzeynepakdag@gmail.com 


\section{Capabilities-based Gender Equality Analysis of Educational Policy-making and Reform in Turkey}

This research aims to scrutinise the latest education reform and education policies in Turkey from a capabilities-based gender equality perspective. The data draws on interviews with stakeholders and practitioners to understand how gender equality is conceptualised in policy-making and to what extent reforms have fostered gender equality in girls' education. From a policy-making perspective, the data shows that reform has been successful in terms of a tangible, measurable outcome of an increase in enrolment rates. This can be attributed to a boost in the number of religious schools and the introduction of single-sex education featuring a limited conceptual understanding of gender equality, with a focus on closing the gender gap. However, from the practitioners' perspective, little concern has been given to gender equality and constrained girls' capabilities. The paper fleshes out the tensions between policy-makers and practitioners by highlighting the need for a comprehensive and inclusive understanding of gender equality in educational policy-making and developing a capabilities-based gender equality policy that is able to dismantle conservative and gendered structures and accommodate boys.

Key words: policy-making, educational reform, Turkey, capability approach, gender equality

\section{Introduction}

Gender is involved in a broad range of inequalities in our world, particularly in relation to education and schooling. Across the world, women's illiteracy remains at 477 million (UIS 2015), while 65 million girls are still not schooled (UNESCO 2015). To address these issues, the Sustainable Development Goals set out to eliminate gender inequalities, provide quality education and equitable access to education for girls and women, and to empower them at all levels by 2030 . Nevertheless, it is too early to foresee if Turkey will be able to achieve these goals; it actually missed the target of universal primary enrolment defined by EFA (education for all) in 2015, which illustrates that there is still a long way to go towards achieving gender equality.

In Turkey, the main concern of gender equality policy has been to bring about gender parity; the evaluative measurement of gender equality has exclusively focused on the quantifiable indicator of closing the gender gap. The Ministry of National Education (MoNE) has launched various campaigns to increase the number of girls in secondary and primary schools and to achieve numerical equality in education (see Cin and Walker, 2016). These campaigns have attained a level of numerical success by significantly increasing the enrolment rate of girls in primary education-from 79 percent in 1997 to 95 
percent in 2016 (MoNE, 2016) - and by providing financial assistance to the most disadvantaged girls in rural and Eastern areas. However, little or no attention has been given to the qualitative and everyday schooling experiences of girls, gender and social relations within and outside schools, the quality of education, patriarchal structures that shape girls' and boys' identities differently, and market and family relations that impact girls' schooling (Cin \& Walker, 2016). This implies that the gender equality aspect of the education agenda in Turkey has a normative conceptual policy goal that relies heavily on tangible and measurable outcomes, which frame an intervention strategy based on numerical parity.

The latest 4+4+4 (4+) education reform, made in 2012, sparked harsh and fervent debates about girls' schooling. The 4+ education reform under the Justice and Development Party ${ }^{1}$ (JDP) government was designed with the aim of democratising the education system. What made the $4+$ significant and distinct from other reforms was that the government sought to use it to wipe the slate clean and completely change the structure of the education system (Inal, 2012, 79). According to the bill, the 4+ reform was necessary due to the difficulties people in "the rural parts of Turkey have gone through", which has stopped them from sending - especially - their daughters to schools (TBMM, 2012, 9). The reform launched a number of initiatives, such as provision for the expansion of religious (imam hatip) schools and promoting open education in an attempt to ensure the continuity of girls' education. However, some consider that the new 4+ education reform challenges MoNE's 20 years of efforts launching legislation, campaigns, and policies to expand girls' schooling (Egitim-Sen, 2013). The reform claims to establish 12 years of compulsory education, but it actually paves the way for students to leave at the end of year four and opt for open education or imam hatip (religious) middle schools, which are provided as a solution to the problem of expanding girls' education. However, there is a lack of scrutiny of the quality of education offered at these schools, the schooling experiences of girls within this education system, and a failure to address the matter of child brides/labour. Although recent figures ${ }^{2}$ (MoNE, 2016) showed some increase in girls' enrolment in secondary schools as many girls started to sign up for open education or enrol at imam hatip schools, the increase in enrolment rates does not necessarily demonstrate equality or quality in education. The policy understanding of equality, which rests on gender parity, cannot address the structural problems girls face, such as how they engage with school, or what and how they learn (Unterhalter, 2005). Therefore, in this research, we aim to provide an analysis of girls' schooling by looking at the 4+ reform and its outcomes on girls' education. Our goal is to understand the initial implications of this reform on girls' schooling from a gender perspective, and to map out whether such a reform, within the context of the current socially and culturally pervasive patriarchal environment of Turkey, can advance the concerns of gender equality in any way. Drawing on the capabilities-based gender equality perspective, we focus on i) stakeholders, i.e. trade unions and

\footnotetext{
${ }^{1}$ AKP is also another acronym used for the Justice and Development Party. AKP stands for Adalet ve Kalkinma Partisi in the Turkish language. The current JDP government has been in power since 2002.

${ }^{2}$ The female enrolment ratio for secondary education increased from $63.86 \%$ in 2011 to $94.36 \%$ in 2016 ; the reform was introduced in 2012.
} 
journalists, as the key actors influencing policy-making and deliberating with decision-makers to elicit the context and the rationale in making the reform, as well as their understanding of gender equality within this reform; and ii) teachers, as the practitioners and first-hand observers of such reforms. The interviews conducted with these groups provided perspectives on the extent to which the new reforms have implications for promoting gender equality and fostering girls' capabilities and freedoms.

\section{Education reforms in Turkey: An overview}

The first major reform, called "the Basic Education Act", was passed in 1997 with the aim of expanding schooling opportunities for all children and increasing girls' schooling, especially in Eastern Turkey; it was also linked to one of Turkey's largest poverty improvement programmes (Dulger, 2004). The programme introduced social policies to advance the conditions of the underprivileged, such as providing free education and health services for the poor and offering free meals and transportation to students coming from low-income families to encourage the schooling of girls and boys (Engin-Demir \& Cobanoglu, 2012). The World Bank guided this programme and provided financial support from 1997 to 2007 to support the country's infrastructural and financial arrangements (McClure, 2014). Following 1997's Basic Education Bill, the 4+ reform was introduced in 2012, representing the most comprehensive educational reform Turkey has ever undergone, being much more wide-reaching than any previous changes, such as a major revision of the primary education curriculum and textbooks in 2004, and the adoption of a more student-centred primary education curriculum in 2005 (Özmen, 2012).

It is important to note that the Turkish education system is highly centralised and all major policy decisions are made by the MoNE (Nohl, 2008), thus leading to a top-down approach in educational policy-making that does not leave room for schools or stakeholders to have autonomy and power in decision-making (Karlidag-Dennis, 2017; Kanci \& Gül-Altinay, 2007). As Karlidag-Dennis (2017) argues, the 4+ education reform (launched in 2012) was likewise introduced with a top-down approach and presented as an essential change to create and promote a democratic and pluralist education and society. The main changes the reform brought were dividing the school system into three levels (primary, middle and secondary) and extending the length of compulsory schooling from eight to twelve years, which paved the way for students to choose between different types of schools at the end of primary school (year four), namely: basic schools (both private and public), vocational schools, and open education. Since there are no other vocational schools that provide middle school education apart from imam hatip (religious) schools (Gün \& Başkan, 2014, 231), this situation led to a debate on whether the $4+$ actually extended the length of compulsory education, or just allowed students to leave basic education at the end of year four and enter religious schools at the age of nine or ten. Imam hatip schools were historically established to train preachers and have been categorised as vocational schools. When the 4+ education reform was passed, it also laid the ground for imam hatip middle schools to be reestablished, which caused extensive discussions and protests from various parts of Turkish society, 
especially among secularists who argued that the 4+ education reform was introduced to promote the imam hatip schools and to decrease the actual length of physical attendance in compulsory education to four years (Güven, 2012). In this view, instead of increasing the compulsory education to twelve years and encouraging students to stay in schools longer, the reform actually "cut the compulsory schooling short and guided students towards open education or apprenticeships at an early age" (Okçabol, 2013, 231). As for girls' schooling, concerns have manifested regarding the potential increase of child brides by allowing girls to drop out after they have completed the first four years of schooling. For one of the leading trade unions, 4+ does not make face-to-face schooling compulsory after the first four years and gives conservative families the flexibility and the leverage to not enrol their children in face-to-face education - especially their daughters - for middle school (Egitim-Sen, 2013 \& 2015). However, the MoNE (2012) denied these allegations, arguing that female students who were not allowed to attend schools with their headscarves could now continue their education as the reform had abolished this ban (from primary school onwards), which could be read as a positive step towards girls' schooling and alleviating the concerns of pious families. Drawing on this controversial debate on girls' schooling, our aim is not to outline the problems of the reform but to analyse it from a capabilities-based gender equality theoretical lens to understand its implications for promoting gender equality beyond merely numerical concerns. To date, a handful of researchers have analysed and critiqued the reform (Gün \& Baskan 2014; Okcabol, 2013) through reviewing the changes the 4+ introduced, but a gender based analysis and understanding has not yet been presented. Therefore, this study aims to provide one of the first feminist analyses of the reform. We now turn to a discussion of a capabilities-friendly conceptualisation of gender equality in education and how such an understanding can have an impact on policy.

\section{Conceptualisations of gender equality in education and policy goals}

Gender is an underpinning rationale that determines how gender equality is conceptualised and approached in education and it manifests itself in three frameworks - human capital, human rights and human development (mainly capabilities) - that play a key role in shaping international legislation, documents, and governments' understanding of gender and gender equality in education. Each of these frameworks features a different - competing, yet complementary — approach to the way gender equality is addressed. The Human Capital theory, for instance, emerged in the early 1970s and focused largely on the gap between girls and boys in enrolment, the distribution of opportunities, and access to education (with regard to teachers, books, transportation facilities, and stipends). This theory elaborated on the economic value of schooling and economic empowerment, with an emphasis on delivering individuals to the labour market (Unterhalter, 2009). Under this approach, women's and girls' education is important to the extent that it reduces the mortality rate, creates more educated families, and contributes to economic growth by fostering their participation in the economy (Unterhalter, 2007a), and gender equality is limited to achieving equality in numbers and closing the gender gap. 
On the other hand, the human rights-based approach recognises the existence of socially constructed gender differences (Vaughan, 2010). Gender equality is understood to involve transformation and reforms in social institutions that perpetuate gender-based inequalities. However, granting rights does not always challenge the power and gender inequalities deeply embedded in institutions if there are no actions and implementations in place to dismantle everyday sexism and unfreedoms. The approach, therefore, ignores the conditions that preclude the operationalisation of these rights (Unterhalter, 2003; Robeyns, 2006), focuses on legalistic solutions to inequalities, and fails to foster sustainable change and address local realities and complexities (Unterhalter, 2009). It therefore has an 'ontologically individualistic' approach to learners (Robeyns, 2003, 65), which means it does not look into social, economic, or political forces that influence gendered experiences within classrooms. However, it is widely used by UN agencies, who regard schools without considering the local contexts they are situated in, and thus do not act responsively towards the lived realities of learners in specific contexts (e.g. by ignoring the needs of communities and students marginalised on the basis of race, caste, tribe, language, and religion). With an emphasis on the enactment of negative freedoms, such as protection from abuse, but not on positive rights, such as one's right to learn in one's mother tongue and to have one's identity reflected in the school curriculum (Tikly \&Barrett, 2011), the rights approach, in general, is not sufficiently supported by political and financial commitments (Robeyns, 2006). By and large, these two approaches, which underlie the dominant normative frameworks of policy goals, do not stipulate a deeper understanding of gender equality; they focus on quantifiable indicators, such as schooling ratio and achievement, with no concern for qualitative indicators, such as experiences or the valued beings and doings of individuals.

As is often the case in debates of gender equality in Turkey, policy development does not aspire to achieve gender justice; however, where it does so, the emphasis is on quantifiable indicators, of closing the gaps and equalising the numbers, as is indicated under the human capital and rights approaches. The absence of such a policy understanding leads to the need to consider the impacts of new education reforms in relation to human development and the expansion of opportunities and freedoms as a necessary indicator of gender equality. Therefore, the conceptualisation of gender equality from the capabilities approach guides us towards a deeper social transformation, not just goals that demonstrate this process in educational settings. In the next section, we conceptualise gender equality from a capability-informed perspective and discuss how it is reflected in policy development and evaluation.

\section{Capability-informed gender equality in education and policy development}

Sen's (1999) capabilities approach is a normative framework for human development based on the ideas of human dignity and social justice. It offers an alternative way of thinking about human well-being in comparison to the theories of utilitarianism, a preference-based or income-based approach, or theories 
of distributive social justice, such as those by Norzick and John Rawl. It looks into the real capabilities of people to function and the opportunities individuals have to realise the functionings that they value. These functionings can be, for example: working, being well-educated, or being safe. Capabilities are the combinations of functionings that a person has the possibility of achieving (Sen 1993, 31), such as having the necessary conditions (hospital, healthcare workers) to recover from an illness. The important point to question is to what extent people have genuine access to their capabilities, and the ability they have to convert the resources/opportunities at their disposal into valuable achievements.

The capabilities approach has generally been used to frame issues of human values, but it has also been widely employed in thinking on education and development, and various dimensions of education, such as inputs (teachers, learning materials, quality of education), the conditions of being educated to support development, and the agency of individuals. Several studies have used the capabilities approach to assess the valued capabilities of girls and women in education (Walker, 2007; DeJaeghere \& Lee, 2011; Cin \& Walker, 2013; 2016), as well as the educational well-being and freedoms of communities and people (DeJaeghere \& Lee, 2011; Okkolin, 2017) by identifying the capabilities that education should promote for gender equality. In particular, some literature draws on Sen's concept of public debate in relation to the capabilities approach and elaborates on the role of participation and public debate in determining valued capabilities and fostering gender justice in education (Alkire, 2002; DeJaeghere, 2012).

With its focus on human freedoms and well-being, the capabilities approach views gender equality in education both as a legal and moral obligation, and as a necessary condition to widen opportunities (Unterhalter, 2007a), promote positive freedoms, scrutinise the conditions of being educated and understand how these aspects influence the functionings valued by each person (Unterhalter, 2007a; Tikly \& Barrett, 2011). It addresses the multiple perspectives of gender equality in education, such as gender discrimination related to learning, the propagation of male and female stereotypes in textbooks, and gender inequalities in the household, the workplace, and the state (Aikman et al., 2011). Additionally, it reconsiders the questions of justice in relation to gender equality, between school and the labour market, non-market settings, institutions, and pedagogies (Walker \& Unterhalter, 2007). Therefore, we can measure gender equality in education, under this approach, by the nature of the education valued by individuals and whether they can achieve their valued beings and doings through education (Unterhalter, 2007b). The approach draws attention to the social and institutional structures that require equity interventions, along with the gender norms, gender roles and identities between social arrangements and individual freedoms (Unterhalter, 2007a). Together, they highlight the importance of considering "possibilities for well-being (through enabling valued functionings), agency expansion and mobilisation (enabling people to participate in their own development according to their own goals), and critically reflecting on one's own values and well-being (through inclusion in the development and policy process)" (Loots and Walker, 2016: 262). 
To integrate the capabilities perspective with policy development, Alkire (2008) proposes two applications of the approach: evaluative and prospective analysis. The evaluative aspect is concerned with which capabilities are expanded, to what extent they are expanded, and for whom; the prospective analysis focuses on how and why capabilities are expanded and on identifying "which concrete actions are likely to generate a greater stream of expanded capabilities" (Alkire, 2008, 32). In this paper, we are concerned with using the primary evaluative role of the capability approach to assess how the new reform has affected particular human freedoms, which opportunities are available, what these freedoms are, and where interventions are needed to expand freedoms. Evaluating policy from the capabilities perspective requires paying attention to the political and social structures influencing policies - such as whose values are being expanded and for which purposes (Eiffe, 2014). This could lead to a prospective analysis to identify the structural changes that would expand the identified capabilities (Loots and Walker, 2016).

We therefore, through a number of interviews with those who have an impact on the policymaking process, and with teachers — as the final practitioners of such policies - aim to explore the policy goals of the new reform, understand where gender equality is placed in its rationale, and highlight how the different conceptual meanings of gender equality have a bearing on implementation. Drawing particularly on teachers' perspectives, specifically those who are in Eastern Turkey, where the immediate effects of such policies on girls' education are easier to see due to the patriarchal nature of the society and communities, we look into the qualitative implications of the reforms on gender equality and girls' schooling.

\section{Methods}

We conducted two sets of 16 interviews in total for this research: the first with 8 teachers, and the second with 8 stakeholders affecting the policy-making process, such as trade unions and journalists. The teachers were working in religious, primary, or secondary schools, and three of them held positions as either principal or vice principal. All the official permissions were obtained from the Ministry of National Education before commencing the data collection, which took place in the Eastern Anatolian city of Van during the 2016-17 academic year. The interviews with teachers aimed to ascertain the educational opportunities and freedoms and the impacts of the new reform on students, along with other gender related issues that the girls themselves may not have been able to identify had we conducted these interviews with them directly. Therefore, we used purposeful sampling of recruiting teachers who had been working in the same school or region for at least 7 years so that they could reflect upon the changes and their experiences with girls in the time since the reform was passed, in 2012. The interviews lasted for approximately 40-50 minutes. None of the participants allowed the researchers to make an audio recording of the interviews due to the state of emergency currently in force in Turkey. The profiles of the teachers are presented in Table 1: 
The second round of interviews was conducted with teacher unions (TUO), $(n=4)$ and journalists (J) $(n=4)$ to gather the opinions of these stakeholders on the relationship between girls' education and the $4+$ reform. These interviews were significant in terms of providing more insight about the policy-making process in Turkey. There were two teacher unions that participated in the interviewing process: EgitimBir-Sen and Egitim-Sen, which are the two major teacher unions in Turkey. Egitim-Bir-Sen is known to have a close relationship with the government since the union's ideological stand is very similar to that of the JDP's (the governing party) liberal-conservative agenda. Egitim-Sen, on the other hand, is an opposition union that is known to criticise the 4+ education reform very openly and supports a secular education system. The members from these unions that participated were the representatives of their local branches. Regarding the journalists, three newspapers were chosen prior to the data collection; however, due to the state of emergency, the names of these newspapers have been kept anonymous. The newspapers were chosen according to their ideological position. To have the most unbiased research possible, the research team tried to talk to both pro-government and opposition newspapers; therefore, the newspapers chosen for this research are mainstream newspapers, but they all hold different views. One of them is known to be pro-government, whereas the other two are less explicit in their political stance, while being more critical of the government's policies. Each of these interviews lasted for around 50-60 minutes. Some of the participants permitted the use of an audio recorder, as long as their names were kept private; some refused to allow an audio recording due to the state of emergency in place in Turkey. Participation in this research was completely voluntary and participants had the right to stop interviews and withdraw from the study at any time. The reason why the study was conducted with stakeholders that influence policy-making and teachers was to examine the implementation of the $4+$ reform and the underlying aims of applying this policy; therefore, we interviewed people who could provide insight on the policy changes. There were two different sets of interview questions for teachers and stakeholders. The interviews with stakeholders provided the researchers with a wider perspective on how education policies are being implemented and established in Turkey and helped to provide an understanding of how they approach the gender equality concerns of the reform. The interview questions with teachers, on the other hand, aimed to elicit their understanding of gender equality and how they viewed the 4+ reform in terms of girls' education in order to explore to what extent the reform played a role in fostering gender equality, both in schools and in the educational lives of students.

For data analysis, firstly, the audio recordings of the interviews were transcribed verbatim, after which the researchers read all of the texts, made notes in the margins, and formed initial codes while highlighting the more significant statements of participants related to the reform. There were around 1015 codes extracted from the data, such as: single sex education, promoting girls' education, gender policy, mixed-gender relations, and cultural values. The coding allowed the researchers to establish the 
themes, such as the understanding of gender equality, conversion factors and girls' capabilities and provided a comprehensive analysis of girls' schooling from a capabilities approach and freedoms perspective by scrutinising the $4+$ reform and its effects on girls' schooling. The body of available literature on the 4+ reform also offered a few codes for the analysis, so the coding process employed emerging codes in order to determine the relevant statements. In the subsequent stage, the meaning or meaning units were listed, and the overlapping and repetitive statements were removed so that clusters and themes appeared. In summary, the data analysis involved examining the data, categorising the sets of data, grouping the sets into similar dimensions and naming them, while extracting the meaning units and emerging themes. The most representative quotations were selected and translated into English.

\section{Results}

Scrutinising the Rationale of the Reform: A Limited and Fragmented Understanding of Gender Equality

Drawing on the interviews conducted with stakeholders as the key actors who have been involved both in the deliberation and policy-making process of the reform, we aimed to highlight how stakeholders approach and understand gender equality within this reform, or to what extent gender equality was given a priority in the policy goals. The interviews showed that there is a limited understanding of gender equality among the key actors, which rests on numerical parity and increasing the enrolment of girls as the sole indication of gender equality. Therefore, the lifting of the headscarf ban at every level of schooling —including primary school — and the establishment of more accessible religious schools (imam hatip schools) were seen as a significant step in expanding girls' access to schools and serving the gender equality aims.

There are many parents who do not send their children to school due to the headscarf ban. I worked both in urban and rural areas and keeping girls at home is more common in rural areas. As the number of religious schools increases, the number of girls who attend school increases, and parents decided to send their daughters to these schools (TOU1).

The new reform claimed to expand girls' freedoms and opportunities by abolishing the headscarf ban at the primary, secondary, and high school level of schooling, thus giving people religious freedom to attend school dressed in a way that they value, thereby reducing the concerns of families who did not want to send their daughters to school. The 'headscarf ban' was a crucial conversion factor that closed the opportunities for many women and girls to access education and employment for several decades in Turkey. However, the policy makers' sole focus on 'access' omits the need to think about gender in relation to 'quality education', and the numerical increase in girls' enrolment and participation is regarded as the only valid way of promoting gender equality. 
Particularly in Eastern Anatolia, there were many families who did not want their daughters to share the same class with boys or who refused to send their daughters to school because they would have to remove their headscarf at schools. There are also families who want their daughters to take religious education. Before the $4+$ reform, they did not want to send their daughters to school but today, they can send them as their daughters are studying at single-sex religious schools. The important thing is that they let their daughters study now. It doesn't matter which school they send them to or what kind of education they get. The point is that those girls can study now. It may be religious education but at least they know what sort of education they are getting and that they are being taught religion related stuff at school (J1).

As seen above, the central concern is to get more girls into schools, with no concern for the quality of education, the school curriculum (except the presence of religious content), the type of female identities or gendered structures being developed, hierarchal and sexist relations or pedagogies within the school, girls' schooling experiences, or gender relations within and outside the schools. Likewise, another official from a trade union also emphasised the importance of the lifting of the headscarf ban, but also criticised the single-sex policy introduced to religious schools:

I am in favour of mixed education, as it better serves the pedagogical and social needs of students and I stated so when this reform was being drafted... yet I believe that lifting the headscarf ban is milestone. Most women who are enrolled in open education (open high schools) are mature women who could not study due to the headscarf ban. Now, more girls will be free to study (TUO2).

In the same manner, another journalist responded to the claims that the $4+$ reform would clear the way for underage marriages, as the bill makes it possible to pursue one's education through open education until the end of high school, by arguing that such comments were purely ideological and have nothing to do with the reform:

Today, women's rights in Turkey are much more progressive than 10 years ago. No one can forcefully marry you, so says the law... I find the claims that the 4+ reform will pave the way for child marriage as an ideological comment made by those who want to oppose this bill... we should wait and see the outcomes of the bill before making such comments (J2).

Although laws in Turkey protect the rights of girls and guarantee that any marriage under the age of 18 is illegitimate and regarded as child marriage, several studies show that girls' consent is still not being sought, particularly in Eastern Anatolia, and that child marriages are still part of the education system that deprives girls of education (Aydemir, 2011; Özaydınlık, 2014). Therefore, the nature of the bill rarely addresses qualitative and gender-sensitive issues; rather, it focuses on boosting enrolment rates. 
What can be inferred from the descriptions of the stakeholders is that the reform does not have a strong gender equality focus; neither does it touch upon the issues that need to be addressed in the education system to strengthen girls' personal development. The central argument and rationale focuses exclusively on the lifting of the girls' headscarf ban as a way to increase girls' participation in school, with no regard for the unequal everyday gender relationships and patriarchal culture promoted both within and outside the schools, nor for broader forms of discrimination related to gender, which have been identified as the major issues that must be addressed to establish broader gender equality within the education system (Cin, 2017; Gumus \& Chudgar, 2016).

The stakeholder interviews show that Turkey has adopted a human capital and rights perspective towards gender equality, meaning girls' access to education is seen as a right. The new reform attempts to ensure this access, but gender is read as a biological category; the opening of more religious schools and the lift of the headscarf ban are seen as making significant progress toward closing the gender gap ensuring that the right of access to education is achieved. Such frameworks draw on policy goals from a reductionist perspective of positioning girls in an enrolment and access setting. Although this is not in tension with human development or gender equality, it is insufficient for gender justice claims in education, which seek to promote moral, political, social and civic thought and entitlement. So, failing to address the persistence of gender inequalities and overlooking socio-cultural influencing factors creating gender inequalities in education is a critical oversight. Such a superficial conceptualisation of gender equality in policy can severely affect the freedoms of girls and constrain their capabilities and exercise of agency. It also leaves in place the structural or social arrangements, as well as other mediating factors influencing their capabilities and their freedom to act on capabilities.

From a capabilities perspective, gender equality in policy-making should seek to promote girls' agency through ameliorating gendered social forces that are shaping girls and boys differently in the school environment, and through providing meaningful education (Unterhalter, 2007a), whilst not ignoring the structures, behaviour and culture that favour or disadvantage boys. Such a perspective is currently missing from the mind-sets of stakeholders and the rationale of the reform. What is more is that the stakeholders' conceptualisation of gender equality heavily depends on girls being primary targets - there is no mention of boys - any policy goals and intervention targeted at gender equality would need to focus on both genders. It becomes evident that boys' schooling, addressing the educational needs of boys or combating the toxic masculinity at schools which places men above women or validates masculine characteristics as markers of domination and strength is less of a concern.

Having pointed out the narrow, fragmented and exclusionary gender equality understanding of the stakeholders in policy-making, we now present the interviews with teachers as the practitioners of this reform to further explore the outcomes of this bill at schools and on girls. 


\section{Implications of the Bill for Gender Equality and Girls' Education: Practitioner Perspectives}

Teachers as practitioners are those who have experienced and have observed the implications and outcomes of the reforms and therefore, can identify the imminent effects of the bill. The data analysis indicates the ways practising teachers experienced the impacts of the 4+ reforms on girls' capabilities in four categories: 1) providing safe schools and efficient learning environments, 2) increasing the enrolment rates of girls, 3) constraining girls' social capabilities, and 4) restricting girls' intellectual capabilities.

\section{Providing Safe Schools and Efficient Learning Environments}

One of the most prominent challenges girls face at schools is an unsafe school environment, with verbal and sexual harassment occurring both within and around schools (Cin, 2017). Teachers argue that the single-sex education offered at religious schools provides girls with a safe, bullying and sexual harassment-free environment to study, and ensures that they can enjoy their physical well-being:

I think separating girls' and boys' classes was a good initiative; girls can act freely, they feel safer, there are no sexual harassment cases [...] In Eastern Anatolia, this kind of harassment is a big deal for families and I think girls are more secure now. It was difficult to prevent such cases in co-education (Mustafa, Vice-principal).

Likewise, another teacher argued that single-sex education made it easier for girls to flourish academically without feeling shame and resentment:

With 4+, girls now receive more positive discrimination. All-girl classes achieve better academically, but in co-education, boys dominate and girls stay on the side lines [...] When it is only girls, they show themselves out there (Canan, teacher).

In general, teachers expressed that the single-sex education provided at religious schools was one way of ensuring that girls who are smart but remain silent can flourish. Girls' silence is often due to feelings of resentment, which could be associated with the patriarchal culture that requires women and girls to develop submissive identities and remain almost invisible in the presence of males. In such an environment, single-sex education can be argued to support and enable girls' intellectual capability of recognising and showing their potential, as well as to secure their physical well-being and provide the necessary conditions to receive education in a safe and harassment-free context.

\section{Increase in Enrolment Rates of Girls}

Girls' enrolment is a fundamental issue for MoNE. Despite the nationwide campaigns and policy initiatives offering positive affirmation, 100 per cent schooling in primary schools has never been achieved for either girls and boys, which is particularly due to the cultural prohibition of girls' education in Eastern Turkey. Therefore, one of the selling points and frequently articulated aims of the new reform 
was to increase the net enrolment rates of girls by increasing the number of religious schools and offering single-sex school as an intervention strategy to convince families to send their daughters to schools. Both the MoNE (2016) figures and teachers in this study support the argument that the schooling ratio of girls, particularly in primary education, has indeed increased:

I can say that the schooling rate of girls has increased since the (single-sex) education respects the cultural values of the community here. Your daughter sharing her class and desk with a male student may not be important for you, but it is very important and unacceptable for people here, to the extent that girls choose to drop-out (Behice, teacher).

I see that families in the village that would not send their daughters to schools do so now because there are religious schools offering single-sex education and single-sex dormitories and all opportunities are being provided for girls to study. [...] So I cannot deny its [4+'s] contribution to the schooling ratio (Cem, principal).

The reform played a crucial role in enabling girls' access to and participation in education; many of these girls would otherwise be kept out of schooling and be pushed toward early marriage. Although the education being provided is religion-based, teachers emphasise that this is what most families in the region (Eastern Turkey) want and it is the main motivation for parents to send their girls to schools. We can speak of the participation of girls in education as an expansion of their intellectual capability to receive education, to gain skills of literacy and numeracy, to access the opportunities and knowledge that could change their lives or open better lives than they lead although we remain sceptical that religious education may not challenge the stereotyping or coding regarding traditional roles of women in the society and family. So, as it stands, the reform does not address how the content and experiences of schooling relate to gender equality.

\section{Constraining Girls’ Social Capabilities}

Despite increasing girls' enrolment and providing a safe and efficient learning environment, the singlesex education adopted by the reform has deprived girls of the opportunity to engage in mixed-gender interactions. Forming such relations is very important for girls raised in patriarchal cultures because it can help to dismantle the gender codes that place them as second-class citizens in comparison to men, and provide a transformative space to appear with boys without shame in a public setting, like school:

Our aim is to socialise the women. Single-sex education displays an understanding distant from secular education and promotes a male-dominated mind-set that allows little freedom for girls and offers a social life only among themselves and, again, teaches them to adhere to oppression in the presence of men (Seda, teacher). 
These girls [girls from a conservative background] do not learn to live in harmony with the opposite sex and how to communicate and interact with them [...] if they are raised like this [in single-sex schools], how will they work with men in the future? (Melek, teacher).

The point made here by teachers was that single-sex education, particularly in patriarchal contexts where gender norms and gender based discrimination are inherent, inhibits girls' social capabilities to establish relations with the opposite sex, speak back, and voice their ideas in mixedgender environments. It also deprives them of a schooling process that could spark a process of recognition that girls could be on par with boys, thus contributing to the production of submissive gender identities and girls who internalise these gender inequalities in their subsequent lives.

\section{Restricting Girls’ Intellectual Capabilities}

The reform also paved the way for open education after primary school, meaning that upon completing the first four years, children may choose to further their education through open education without physically attending school, but just sitting for exams.

Parents can choose not to send their daughters after primary schools and there have been cases like this; they marry girls off (by unofficial imam marriage) and get them registered in open education. How can a girl in open education achieve the same as one in formal education and further her education? It cuts the girl out of school life and deprives her of all the social and intellectual gains and life she could have had (Serdar, teacher).

The flexibility for open education, despite the increase in enrolment rates, works as a disadvantage for some girls and keeps them away from school, which in turn limits their interaction with their peers, teachers, and social/intellectual facilities provided by school. Socialising is also a chrysalis for democratic values as students get to meet other students who are like not like-minded and not of the same class and respect them rather than living in a nutshell. Therefore, such interactions could help them develop the intellectual capability of developing aspirations, expanding their horizon and gaining knowledge and basic life skills; developing these capabilities leads to further capability development, as education has a distributive and interpersonal effect in reducing gender inequalities and expanding all other capabilities (Sen, 1999), as well as contributing to diversity and progression in society and community.

\section{Discussion}

\section{What a capabilities-based gender equality in education policy-making could offer?}

The interviews with stakeholders who have directly or indirectly taken part in the reform reinforced our argument that Turkey has a limited vision in approaching gender equality in educational policy-making. Although we agree that providing women and girls access to education and increasing their participation 
is a significant step, it is insufficient in terms of coping with wider gender inequalities that disempower girls and women, preventing them from achieving what they value and challenging the norms, structures, relations and hierarchies that reproduce such inequalities. Therefore, a capabilities-based gender equality would require addressing conversion factors of gendered relations, structures, pedagogies, practices and beliefs that work as barriers to girls' widening their opportunities and capabilities and achieving well-being (Unterhalter, 2007a). The current reform does not comprehensively provide clear, in-depth policy goals and definitions of achieving gender equality that could bring transformative changes; therefore, the use of capabilities to inform policy goals would reduce the influence of the aforementioned conversion factors in education on girls' capabilities and agency.

The limited understanding that shaped the reform and policy was also reflected in its practices. It constrained girls' social capabilities of engaging freely in mixed-gender relations without harassment and shame, which could have been provided only through schooling due to the prevailing cultural values and social monitoring effectively regulating their bodies in the community. The reform also inhibited the development of girls' intellectual capability of benefiting from the cultural, intellectual and social facilities provided by school, which are of great importance for the development of further capabilities. The tension between the intentions of policy and how it is practiced is evident and it results from the issue of minimum compliance, meaning gender equality in education is a long-established and aspired for goal in Turkey, yet aiming at enrolment indicates the minimum commitment to this goal grounded in a political and moral vision.

These findings not only address the necessity of integrating capabilities-informed gender equality in policy-making, but also highlight the significance of adopting a bottom-up approach that could transform gender inequalities. A policy understanding that does not create alternative space for bottom-up needs, listen to the voices of practitioners who could better identify the needs and structural problems, conversion factors or bring the voices of girls to the forefront cannot foster gender justice. A top-down approach with no public debate and deliberation with communities, practitioners, or girls, can only promote economic development by ensuring that a certain number of girls are in the education system, but cannot address the qualitative aspects of gender equality that could improve girls' and women's lives. Therefore, establishing policy goals requires bottom-up contributions where problems such as implementation, negative conversion factors, and structural and relational challenges arising from the top-down approach can be identified and used to serve as an informational basis for policy development. A failure to do so would only reflect the political and power influences shaping policies, as in the $4+$ reform, in which neo-conservative values (introducing religious values both in their programs and political behaviour) and the agenda of the government are partially incorporated in education system. As a result, the reform sets a moral-religious compass for education and creates a culture based on religiosity through promoting single-sex education within the religious schools and prioritising these schools. 
We argue that Turkey needs a comprehensive understanding of gender equality in educational policy-making that could dismantle conservative and gendered structures, which would also focus on boys. These structures impact girls' schooling experiences, opportunities, and access; challenging them would build a more gender just society, which is identified in the SDG goals that Turkey ratified and is explicitly stated in the development goals of the government. A capability-informed gender equality has a lot to offer in thinking about how to transform social structures, confinements, and institutions to empower girls and give them room to manoeuvre to achieve their interests and aspirations. Considering the vast number of initiatives and campaigns launched in collaboration with MoNE, NGOs, and the EU (see Cin \& Walker, 2016) to promote gender equality in schools, we argue that the issues surrounding equality and girls' empowerment are still priority issues for the government. However, lack of political will in reflecting these into policy goals and outcomes has withheld transformative changes that could promote sustainable gender equality.

\section{Conclusion}

This research offers an analysis of the 4+ reform from a capabilities-based gender equality perspective by drawing on 16 interviews conducted with stakeholders and practitioners. We cannot generalise the outcomes of the reforms on girls in Turkey, as we only conducted interviews with teachers in Eastern Anatolia, where the gendered norms are most stratified. Nevertheless, the results reveal the underpinning rationale in terms of how little concern is given to gender equality and how it impacts girls' educational experiences - yet we could see that both practitioners and stakeholders influencing the decision makers keep boys' education out of gender equality claims and take girls as the point of reference. Although the education and schooling of girls in Turkey is more at stake than that of boys, single-sex education equally deprives boys of mixed-gender relations and the opportunity to mingle or communicate with the opposite-sex and does not address the toxic masculinity embedded in pedagogy, curriculum, school structures and gender relations. Similarly, initiatives that only focus on promoting girls' education and boosting their numbers can overlook the boys who do not have the necessary economic means to study, all of which is significant for building a gender-just society. Therefore, it is time that we moved towards a more inclusive understanding of gender that incorporates boys and engages them in gender equality initiatives.

We believe that the outcomes and impacts of the reform should be thoroughly analysed across the country to address its lack of gender equality conceptualisations. It is hoped that the findings will inform the debates on gender equality within the reform, as they allow us to conclude that traditional gender roles and patriarchy are not being challenged in schools; on the contrary, the policies adopted with the aim of improving women's educational and social lives seems to have widened the separation between males and females. Even though the government prioritises girls' education and equality agenda, there are obstacles to overcome, such as tackling the cultural norms surrounding girls, introducing a 
comprehensive understanding of what gender equality is, and applying this in schools. More importantly, there is a need to adopt a bottom-up approach; the inclusion of teacher trade unions and journalists in policy-making is important but insufficient in matters such as gender inequality; instead, girls, boys, communities, and practitioners in the field should be the first to inform such policies.

\section{References}

Aikman, S., Halai, A., Rubagiza, T., 2011. Conceptualising gender equality in research on education quality. Comp. Educ. 47 (1), 45-60.

Alkire, S. 2002. Valuing freedom's: Sen's Capability Approach and Poverty Reduction. New York: Oxford University Press.

Alkire, S. 2008. "Using the Capability Approach: Prospective and Evaluative Analyses." Chap. 1. In The Capability Approach: Concepts, Measures and Applications, edited by F. Comim, M. Qizilbash, and S. Alkire, 26-49. Cambridge: Cambridge University Press.

Aydemir, E. 2011. Evlilik mi evcilik mi? Erken ve zorla evlilikler: Çocuk gelinler. International Strategic Research Organization (USAK).

Cin, F. M. 2017. Gender Justice, Education and Equality: Creating Capabilities for Girls' and Women's Development. Springer.

Cin, F. M., \& Walker, M. 2013. Context and history: Using a capabilities-based social justice perspective to explore three generations of western Turkish female teachers' lives. International Journal of Educational Development, 33(4), 394-404.

Cin, F. M. and M. Walker. 2016. Reconsidering girls' education in Turkey from a capabilities and feminist perspective. International Journal of Educational Development, 49, 134-143.

DeJaeghere, J. 2012. "Public Debate and Dialogue from a Capabilities Approach: Can It Foster Gender Justice in Education?” Journal of Human Development and Capabilities, 13, 353-371.

DeJaeghere, J., and S. K. Lee. 2011. "What Matters for Marginalized Girls and Boys in Bangladesh: A Capabilities Approach for Understanding Educational Well-being and Empowerment." Research in Comparative and International Education, 6(1), 27-42.

Dülger, I. 2004. “Case Study on Turkey: Rapid Coverage for Compulsory Education Reform”. Paper presented at the annual meeting for the Conference on Scaling Up Poverty Reduction Shanghai, China May 25-27. 
Egitim-Sen. 2013. “11 Eylül Dünya Kiz Çocuklari Gunu'nde Turkiye'de Hala Cocuk Gelinler ve Cocuk Isciler Var." [There is Still Child Bride and Child Labour at the Day of World Girls' on $11^{\text {th }}$ September in Turkey]. Accessed 20 August 2017. http://egitimsen.org.tr/11-ekim-dunya-kizcocuklari-gununde-turkiyede-hala-cocuk-gelinler-ve-cocuk-isciler-var/

Egitim-Sen.2015. “2014-2015 Egitim Ogretim Yilina Baslarken Kiz Cocuklari Egitim Sisteminin Neresinde?" [ While We Are About to Start 2014-2015 school year and Where Do Girls Stand in the Education System?] Accessed 18 December 2017. http://egitimsen.org.tr/2014-2015-egitimogretim-yili-baslarken-kiz-cocuklari-egitim-sisteminin-neresinde/.

Eiffe, F. F. 2014. "Implications for a Capability-Based Social Policy: A European Perspective." In Enhancing Capabilities: The Role of Social Institutions, edited by H. U. Otto and H. Ziegler, 3954. Opladen: Barbara Budrich.

Gumus, S., and A. Chudgar. 2016. "Factors Affecting School Participation in Turkey: An Analysis of Regional Differences." Compare: A Journal of Comparative and International Education, 46(6), 929-951.

Gün, F., and G. A. Baskan. 2014. "New Education System in Turkey $(4+4+4)$ : A Critical Outlook." Procedia - Social and Behavioral Sciences. 131, 229-235.

Güven, I. 2012. "The 4+4+4 School Reform Bill and the Fatih Project: Is It a Reform?” Elementary Education Online, 11(3), 556-577.

İnal, K. 2012. "The educational politics of the AKP: the collapse of public education in Turkey. Neoliberal transformation of education in Turkey political and ideological analysis of educational reforms in the age of AKP." New York, Palgrave Macmillan.

Karlidag-Dennis, E. 2017. Basic Education and Hegemony: Thinking on Ideology, Policymaking and Civil Society. University of Nottingham. Unpublished $\mathrm{PhD}$ thesis.

Kanci, T., and Altinay, G. 2007. "Educating Little Soldiers and Little Ayses: Militarised and Gendered Citizenship in Turkish Textbooks". Education in Multicultural Societies: Turkish and Swedish Perspectives. 52-70. Swedish Institute in Istanbul.

Loots, S., and M. Walker. 2016. "A Capabilities-based Gender Equality Policy for Higher Education: Conceptual and Methodological Considerations." Journal of Human Development and Capabilities, 17(2), 260-277. 
McClure, K. R. 2014. "Education for Economic Growth or Human Development? The Capabilities Approach and the World Bank's Basic Education Project in Turkey." Compare: A Journal of Comparative and International Education, 4(3), 472-492.

Ministry of National Education.2012. 12 Yil Zorunlu Egitim Sorular-Cevaplar. Ankara. [Online] Available at: http://www.meb.gov.tr/duyurular/duyurular2012/12Yil_Soru_Cevaplar.pdf.

Ministry of National Education. 2016. "National Education Statistics: Formal Education 2015/2016." Accessed 21 July 2017. http://sgb.meb.gov.tr/meb_iys_dosyalar/2016_03/18024009_meb_istatistikleri_orgun_egitim_2 015_2016.pdf

Nohl, A. 2008. "The Turkish Education System and Its History." In Education in Turkey, edited by Nohl, A. M., A. Akkoyunlu-Wigley, \& S. Wigley (Eds.), 15-48. Munster: Waxman.

Nussbaum, M. 2000. Women and Human Development: The Capabilities Approach. Cambridge: Cambridge University Press.

Özaydınlık, K. (2014). Toplumsal cinsiyet temelinde Türkiye'de kadın ve eğitim. Sosyal Politika Çalışmaları Dergisi, 33, 93-112.

Özmen, Ü. 2012. "The Marketization of Primary and Secondary School Curricula and Textbooks Under AKP Rule." Neoliberal Transformation of Education in Turkey Political and ldeological Analysis of Educational Reforms in the Age of AKP.MacMillan.

Okçabol, R. 2013. AKP Iktidarinda Egitim: Egitimin Piyasalasmasi ve Gericilesmesi [Education in AKP Government: Being Marketable and Reaction of Education]. Ütopya Yayinevi. Ankara.

Okkolin, M. A. 2017. Education, Gender and Development: A Capabilities Perspective. Routledge.

Robeyns, I. 2003. “Sen's Capability Approach and Gender Inequality: Selecting Relevant Capabilities." Feminist Economics, 9, 61-92.

Robeyns, I. 2006. “Three Models of Education: Rights, Capabilities and Human Capital.” Theory and Research in Education, 4, 69-84.

Sen, A. 1993. "Capability and Well-being." In The quality of life, edited by Nussbaum M. and A. Sen (Eds.), 30-53. Oxford: Clarendon Press. 
Sen, A. 1999. Development as Freedom. Oxford: Oxford University Press.

Türkiye Büyük Millet Meclisi Başkanlığı (TBMM). 2012. ilköğretim ve Eğitim Kanunu ile Bazı Kanunlarda Değişiklik Yapılmasına Dair Kanun Teklifi. Ankara: TBMM.

Tikly, L., and A. Barrett. 2011. "Social justice, capabilities and the quality of education in low income countries." International Journal of Educational Development, 31, 3-14.

UIS (UNESCO Institute for Statistics) 2015. Adult and youth literacy, fact sheet, September, no. 32. Montreal, Canada, UIS.

UNESCO 2015. "Education 2030: Incheon Declaration and Framework for Action: Towards Inclusive and Equitable Quality Education and Lifelong Learning for All." Accessed 18 May 2016. http://www.unesco.org/new/fileadmin/MULTIMEDIA/HQ/ED/ED new/pdf/FFA-ENG27Oct15.pdf $\% 20$

Unterhalter, E. 2003. "The Capabilities Approach and Gendered Education: An Examination of South African Complexities." Theory and Research in Education, 1(1), 7-22.

Unterhalter, E. 2005. "Fragmented Frameworks: Researching Women, Gender, Education and Development." In Beyond Access: Developing Gender Equality in Education, edited by Aikman, S.and E. Unterhalter (Eds.), 15-35. Oxford: Oxfam.

Unterhalter, E. 2007a. Gender, Schooling and Global Social Justice. Oxon: Routledge

Unterhalter, E. 2007b. “Gender Equality, Education, and the Capability Approach.” In Amartya Sen's Capability Approach and Social Justice in Education, edited by Walker M. and E. Unterhalter (Eds.), 87-107. New York: Palgrave Macmillan.

Unterhalter, E. 2009. "Social Justice, Development Theory and the Question of Education." In International Handbook of Comparative Education, edited by Cowen R.and A. M. Kazamias (Eds.), 781-800. London: Springer.

Vaughan, R. 2010. Girls' and Women's Education within UNESCO and the World Bank, 1945-2000. Compare: A Journal of Comparative and International Education, 40(4), 405-423.

Walker, M. 2007. Selecting Capabilities for Gender Equality in Education. In Amartya Sen's Capability Approach and Social Justice in Education, edited by Walker M. and E. Unterhalter (Eds.), 177196. New York: Palgrave Macmillan. 
Walker, M., and E. Unterhalter. 2007. Amartya Sen's Capability Approach and Social Justice in Education. New York: Palgrave Macmillan. 